
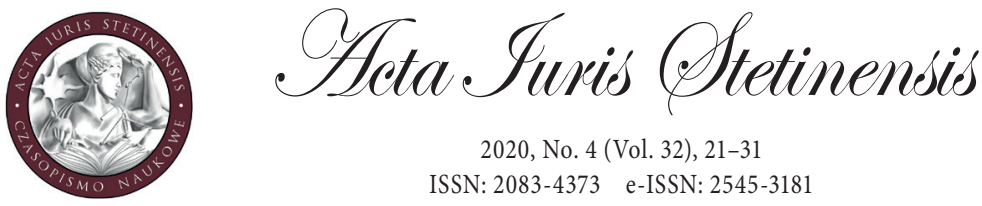

2020, No. 4 (Vol. 32), 21-31

ISSN: 2083-4373 e-ISSN: 2545-3181

DOI: 10.18276/ais.2020.32-02

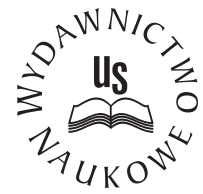

Michał Matuszak

Ph.D.

University of Lodz, Poland

Faculty of Law and Administration

e-mail: matuszakmm@gmail.com

OPEN ACCESS

ORCID ID: 0000-0003-2794-3634

\title{
Work-life balance among athletes
}

\begin{abstract}
The application of the work-life balance concept has become increasingly popular in recent years. This concept draws not only from legal solutions, but from psychological sciences and those related to human resources management. In the field of labour law, the instruments used may be, inter alia, rights related to parenthood (maternity, paternity, parental and extended parental leave), the use of fixed-term contracts or part-time employment, the use of individual working time schedules, the use of task-based schedules, equivalent or intermittent working time, telework regulations, variable work start and end times.

However, employment in professional sports is atypical. The very essence of providing sports work is different from the essence of performing both office and industrial work. It consists in the provision of a special type of work of a multiple nature aimed at maximising the performance of athletes, carried out for profit. The athlete's ability to achieve success results from the effect of actions taken as part of the employment relationship with the club as well as from leisure activities. Such activities include preparing appropriate meals, keeping a balanced diet, refraining from an unhealthy lifestyle and from the use of unauthorised substances, not using drugs that could be considered doping, taking care of proper regeneration and rest, and refraining from betting on matches in the practiced sport discipline.

Herein, firstly, the characteristics of sports work was presented and, secondly, the possibilities of using work-life balance tools in shaping everyday sports work were analysed. The paper analyses the blurring of personal and professional lives among athletes. The main conclusion of the paper is the inability to effectively guarantee a work-life balance among
\end{abstract}


athletes, and that athletes can effectively use legal tools of WLB only if they simultaneously perform services or work elsewhere.

The paper uses a dogmatic and legal method (analysis of the literature, analysis of normative acts) and the results of research carried out by the author, i.e. a survey addressed at professional athletes.

Keywords: athlete, work-life balance, working time, sports law

\section{Introduction}

In the 21st century reality, issues of over-engagement of employees in the working process are phenomena of strong social nature, which, by its intensification, have a direct impact on all other spheres of a human's life, including family and health. There are numerous works on the topic of the many reasons for organising one's own life around work. Currently, the concept which meets with the greatest approval among employees, as well as more broadly among researchers dealing with the world of work, is the so-called work-life balance (WLB), which assumes such time management that allows achieving a balance between work and private life and, as a result, achieving objectives in compliance with personal principles and rules. However, the feeling of this balance or a lack thereof will be different for different persons, since it is subjective and individual. ${ }^{1}$

Simultaneously, it should be indicated that WLB is not strictly a legal issue, and should rather be treated as a broader issue related to human resources management and psychology. Nevertheless, there are legal constructions primarily included in the Labour Code, which indirectly allow the maintenance of a WLB. In particular, those that address issues of working hours or the right to a holiday leave are the most useful.

Difficult to define, WLB is a concept that can be analysed at many various levels. The primary difficulty consists in defining what life or a life might be, which for each athlete (player) can mean something else. We can consider its various aspects, among others: family, social, home, as well as other activities, and so forth: duties, rest, hobby or recreation. ${ }^{2}$ The relations between the professional sphere, private

1 Tausig, M. and Fenwick, R., Unbinding time: alternate work schedules and work-life balance, "Journal of Family and Economic Issues" 2001, Vol. 22(2), pp. 104-105.

2 Hildt-Ciupińska, K., Work-life balance a wiek pracowników, "Bezpieczeństwo Pracowników" 2004, No. 10, p. 17. 
sphere and family sphere remain the main object of research of persons dealing with the topic of WLB. ${ }^{3}$

Unfortunately, persons dealing with the topic of balancing professional life and private life do not present too many instruments that make it possible to determine which activities fall under which sphere, with a relatively precise indication of a demarcation line. The literature indicates numerous difficulties with capturing this issue and ongoing processes of blurring these two spheres. It should be noted that the vast majority of scientific works in this scope concern 'classic performance of work' in which it is undoubtedly difficult to include performance of sports work.

Maintenance of the WLB concept is currently one of the priorities of the European Union. ${ }^{4}$ Legal scholars and commentators describe this area as the one that allows improving the quality of a person's life. ${ }^{5}$ In its essence it concerns each person who performs gainful employment, and not only women during motherhood, an issue to which the largest number of studies are devoted. ${ }^{6}$ Any instruments in the scope of WLB should be applied with a consideration of the variety of life situations of employees and their individual preferences so that it is possible to achieve the assumed results. ${ }^{7}$

The main goal of this study is to analyse the possibilities of professional athletes to use WLB tools, and as a result of the above to identify possible threats that result from the specific conditions of performing sports work in this area. The research problem remains relevant, given the increasing number of players who practice sports for commercial purposes. As a consequence of the above, the following thesis was verified: due to the unique nature of sports, which is intensified by its commercialisation, athletes can use only some of the tools included in the WLB concept.

This paper uses a dogmatic and legal method (analysis of the literature, analysis of normative acts) and presents the results of the research conducted by the author a survey addressed to professional athletes, which was conducted between December 2018 and July 2019. The questionnaire consisted of seventeen closed-ended

3 Pietras, A., O zakresie podmiotowym prawa pracy z perspektywy koncepcji work-life balance, "Acta Universitatis Lodziensis. Folia Iuridica”, 2019, No. 89, p. 59.

4 Crompton, R. and Lyonette, C., Work-life 'balance' in Europe, “GeNet Working Paper” 2005, No. 10, pp. 3-7, https://journals.sagepub.com/doi/abs/10.1177/0001699306071680 (accessed 02.12.2019).

5 Guest, D., Perspectives on the study of work-life balance, "Social Science Information” 2002, Vol. 41, Issue 2, pp. 256-258.

6 Fleetwood, S., Why work-life balance now?, "Lancaster University Management School Working Paper" 2006, No. 41, pp. 1-3.

7 White, M. et al., 'High-performance' management practices, working hours and work-life balance, “British Journal of Industrial Relations” 2003, Vol. 41, Issue 2, pp. 191-193. 
questions and one extended question in which individual elements of sports work had to be assigned their significance (key, important, average, unimportant, completely irrelevant). The method applied in the research was a quasi-representative survey, which was direct and anonymous and was carried out by using a standardised questionnaire. In my opinion, from the point of view of the labour law, using this concept in many specific areas of employment is extremely problematic. Herein, I will present my doubts in detail with an example of the situation of professional athletes. They are a specific occupational group, whose everyday image of performing work is different from the 'typical' 'office' work which most often is the object of analysis in the context of maintaining WLB.

\section{Characteristics of sports work}

Maintenance of a proper balance between the number of professional duties and the possibility of the employee's personal fulfilment in the private sphere is crucial for the long-term guarantee of the full use of their potential. ${ }^{8}$ At the same time, balance should not be identified with effectiveness. ${ }^{9}$ In the reality of the present nature of professional sports, this is an extremely important factor, which allows achievements in both individual and team sports. A player is, in fact, obliged to act inside a dual system: first of all, in a system that maximises their psychophysical abilities allowing achievements in sports, and secondly in a system that allows maintaining the long-term ability to compete in sports across consecutive sports seasons.

The characteristics of professional sports create numerous difficulties in arriving at a precise determination of where the performance of sports work ends and where the time for leisure and for all other elements comprising the whole of private life begins. To a certain extent these difficulties are identified with the issue of indicating athletes' working time, which can include, among others, activities such as: training; work with a psychologist and a dietician; gym workouts; doing other recommended sports (e.g. swimming); marketing activity; participation in marketing and promotional meetings; maintaining social media accounts; undergoing physical therapy and preparing meals and nutritional supplements in compliance with individual psychophysical needs. Defining a rigid boundary between work

8 Robak, E. and Słocińska, A., Równoważenie pracy z życiem osobistym pracowników jako istotny czynnik warunkujący gospodarowanie wspótczesnymi zasobami pracy, "Studia Ekonomiczne. Zeszyty Naukowe Uniwersytetu Ekonomicznego w Katowicach” 2016, No. 257, pp. 159-160.

9 Riordan, C., Work-life balance - tu nie chodzi o równowage, https://www.hbrp.pl/b/work-life-balance---tu-nie-chodzi-o-rownowage/DQ725mbo?NO_COOKIES=1 (accessed 02.12.2019). 
and private life is extremely difficult. Sometimes it is impossible, especially considering the fact that a player does not have full autonomy in decision-making with respect to the majority of the aforementioned activities.

For the purposes of this paper, it is sufficient to employ a simplified definition of sports work, which can be understood as: work consisting of the performance of a specific type of work of a varied nature, performed by athletes in order to fulfil particular needs of sports fans consisting in maximisation of achieved sports results and performed for employment purposes. ${ }^{10}$

Maximisation of achieved sports results is a derivative of maintaining proper physical and psychological fitness by the athlete. It should be underlined that maximisation of results achieved by the athlete depends on many factors, whereas some of them remain outside the sphere of the athlete's direct impact. Undoubtedly, without a stable private life that is directed at a healthy lifestyle, it is much more difficult to achieve the dream objectives in sport. Therefore, separating professional and private lives is almost impossible.

It should be underlined that keeping a high level of fitness by athletes is important for them as well as for the sports club in which they play. A player is usually affiliated with a parent sports club on the grounds of an employment relationship or a civil law relationship.

\section{Athletes' duties at particular stages of their careers}

Before proceeding to further discussion, it should be indicated that the athlete's everyday duties and thus their schedule change at various stages of their careers and differ depending on the practiced sport discipline. ${ }^{11}$

At the stage of a junior career (first stage) a player is obliged to reconcile training with school duties. Available biographies of professional athletes imply that during this period of time their schedules were very similar. They usually got up two, three hours before starting classes at school in order to prepare for them and directly

10 The author included complex reflections on the definition of sports work and its components in his doctoral thesis entitled 'Sports Contract'. In the author's opinion, for the purposes of the discussion on a work-life balance of athletes herein, a simplified definition of sports work, which allows complex understanding of its essence and, in particular, understanding interference of athletes' professional and private life as an inherent feature of performing sports work, is fully sufficient. For greater familiarity with more in-depth reflections concerning sports work, I would encourage reading the aforementioned doctoral thesis.

11 Precise specification of the stages of a sports career is significantly impeded due to, first of all, the individual course of each career, secondly, individual conditions, and thirdly, significant differences among particular sports disciplines. 
after classes they started training at their sports clubs. Sometimes, training was held twice a day - before and after school.

At the stage of a proper career (second stage), a player trains professionally in a given discipline and participates in particular competitions of championship rank. During this period of time, an athlete has the greatest achievements and thus gains the highest income.

In the Code of Good Governance for Polish Sports Associations, the Ministry of Sport and Tourism provided absolute guidelines binding for Polish sports associations consisting in promoting dual careers among players and coaches consisting in ensuring a parallel educational or professional path for players, which allows them to smoothly enter the labour market after ending their sports careers. ${ }^{12}$

At the stage of sports retirement (third stage) a player no longer participates professionally in competitions of championship rank. They also look to other means of earning an income. Sometimes players are interested in related possibilities concerning the previously practiced discipline, including continuing the career as a coach, an activist, a scout, a sports journalist, etc. Some of them establish their own training centres and sports academies under their own names. After ending their careers, some former athletes in a way abandon their roots and start an activity in completely different fields of endeavour. Athletes who during their career accumulated significant funds can spend several years on their passions and achieve personal goals, achievement of which was not possible during their proper career.

Reflections herein concern the stage of junior and proper careers and thus, the stages where there are significant difficulties with maintaining proportions between sports career, education, other gainful employment and personal life.

Due to its significant impact on other activities undertaken by the athlete in his or her private life, sports work seems to penetrate the sphere of private life even more deeply than is the case with work outside the realm of professional sports. In their leisure time the athlete is usually obliged to heed the recommendations of the coaching staff, club doctors, dieticians, and physical therapists, to constantly inform the club of one's whereabouts (with regard to the duties resulting from antidoping controls) as well as observe prohibitions regarding consumption of alcohol or drugs, smoking, and the taking of medications which could be regarded as doping, participation in evening events, placing oneself in jeopardy of injury by engaging in physically risky sports disciplines (e.g. skiing), avoiding a sedentary lifestyle and participation in gambling consisting in predicting results of one's own sports

12 Kodeks Dobrego Zarządzania dla Polskich Związków Sportowych, Ministry of Sport and Tourism, Warszawa 2018, https://www.msit.gov.pl/pl/aktualnosci/7622,Kodeks-Dobrego-Zarzadzania-dlaPolskich-Zwiazkow-Sportowych.html (accessed 02.12.2019). 
discipline matches, as well as any other activities that could have an impact on the current or long-term fitness or the possibility to compete in a given competition in compliance with the internal regulations of a specific sports association.

\section{Legal and organisational instruments facilitating reconciliation of professional work and private life}

The existing instruments facilitating reconciliation of professional work and private life can be divided into legal instruments resulting from legal constructions adopted by the legislator in particular acts and organisational instruments primarily implemented by factual activities of an employer in particular workplaces.

In the current legal state there are certain solutions allowing implementation of the WLB concept within the employment relationship including, among others, existence of rights related to parenthood (maternity, paternity, parental leave), using fixed-term contracts, the possibility of part-time employment, application of an individual schedule (Article 142 of the Labour Code), using the possibility to apply task-based schedule (Article 140 of the Labour Code), equivalent working time (Article 135 of the Labour Code), provisions concerning teleworking (Article 67(5) of the Labour Code et seq.), flexible working hours (Article 140(1) of the Labour Code), reduced working week (Article 143 of the Labour Code), work performed on weekends (Article 144 of the Labour Code) or job sharing. ${ }^{13}$

The Labour Code does not constitute an independent barrier in effective application of the WLB concept, since there are such legal constructions which can be effectively applied by the parties to the employment relationship. The factual situation of particular employees is usually inhomogeneous, therefore, different instruments may seem to be proper for each employee. It is true that there is not a single effective universal-character model of maintaining balance between professional and private lives of an employee.

An employer can, in the scope of his competences, undertake certain further organisational activities, which can be understood more broadly as organisational instruments in the scope of WLB. Such activities of the employer can include, among others, introduction of care provided for children at the workplace, reducing overtime, allowing the possibility to perform work remotely, ${ }^{14}$ introduction

13 Job sharing is not regulated in Polish provisions and the essence thereof consists in organising work so that the total number of working hours of two or more employees fills one full working time.

14 Ibidem, pp. 14-15. 
of a system of both financial and non-financial bonuses which are awarded to employees forced to reconcile work with care duties.

Furthermore, sometimes an additional group of instruments directed at building a proper atmosphere amenable to persons managing family and professional roles, which is to contribute to the perception of work as a value and additionally improve satisfaction therefrom, is indicated by legal commentators. Undoubtedly, each case of introduction of the work-life balance concept is, in essence, an interdisciplinary project which usually uses various legal and organisational instruments.

Using the above legal and organisational tools is still not very popular in Poland. Their actual use most often results from the single interest of the employer and not the individual situation of the employee. Nevertheless, it should be indicated that using WLB tools generates long-term benefits for employers by, among other things, the improvement of their image, thus increasing their attractiveness as employers to valuable persons on the labour market and improving the work motivation of current employees. ${ }^{15}$ The aforementioned benefits are crucial for achieving set objectives by sports clubs in both national and international competitions.

The use of the instruments of increasing flexibility of an employment relationship may paradoxically result in increased blurring of boundaries between the work sphere and the private life. Almost unlimited possibilities of contacting the employee via remote communication tools and performing a part of work in the domicile, ${ }^{16}$ in the so-called home-office system, in the long run causes immanent interpenetration of these two spheres sometimes resulting in the impossibility to properly perform duties both at work and in private life.

\section{Limited use of legal instruments for effectiveness of professional athletes' of work and family life}

While performing sports work, athletes cannot effectively use many tools of making their work more flexible due to the essence of the performed work. Sports work consists in many activities, among others, participation in sports competitions, training, and marketing, which in the main requires the athlete to appear in person at a given place and time. There is not much room for moving these time and space frameworks. There are, in fact, fixed schedules of sports competitions which force athletes to perform the aforementioned activities in strict set conditions. There is

15 Raport $z$ pogłębionej analizy danych zastanych: rozwiąania na rzecz godzenia życia zawodowego i rodzinnego $w$ Polsce, October 2016, No. 10, www.kapitalludzki.gov.pl (accessed 30.12.2019). 
a possibility of a certain interference in the time framework of the athlete's training so as not to affect their current fitness, to allow them to reconcile their sports career with their education or the performance of other gainful employment in order to earn a living and pay for training.

A professional sports career does not allow closing it within the tight framework of several hours of work per day. Legal instruments in the scope of WLB focus on guaranteeing the employee the possibility of limiting working hours or introducing periods free of the obligation to provide work. Effective performance of sports work is strictly correlated with the player's organisation of his or her private life. Therefore, in my opinion, using available legal instruments will not be effective with regard to athletes due to the characteristics of their work, which has been presented herein in detail. The essence of performing sports work does not consist in performing work for a specific period of time (as in the case of, among others, cashiers) or in producing of a specific number of products (as in the case of piecework), but achieving synergy within the framework of performed sports work which would allow maximisation of fitness and thus allow significant sports achievements. In consequence, it is necessary for both parties to the employment relationship to keep the athlete in good physical and mental condition, which can be executed indirectly with tools included in the implementation of the work-life balance, which, however, in essence are not aimed at maintaining a balance between private and professional life, but in all instances maximising the player's fitness. Nevertheless, the existence of this balance can be in practice a side effect of a joint fight of both parties to the employment relationship for the highest sports goals.

However, the possibilities to use legal instruments to make the employment relationship more flexible may be utilized in the context of other gainful employment performed by the athlete, so that they can reconcile performance of other employee duties with those resulting from the performance of sports work, in particular, in the scope of keeping their high level of psychophysical fitness. Undoubtedly, performance of full-time gainful employment in a basic work system usually does not allow one to commit themselves to a sports discipline at a championship level. However, in such a situation, there will be no case of implementing the worklife balance concept in the strict sense, since it means reconciling professional work with private life and not combining two different employment activities.

\section{Conclusions}

Application of WLB, irrespective of the differences in understanding it as underlined in legal writings, should be considered necessary and in the long run beneficial for 
both parties, i.e. the employer (the principal) and the employee (the contractor). The athlete is an individual who is especially prone to blurring boundaries between his or her sports work and private life. Irrespective of the legal grounds for the performance of sports work i.e. the civil law contract or the employment agreement, the possibilities of using tools to make work more flexible are not significant. It should be noted that to a significant extent the employee status and the civil law status of athletes is greatly standardised due to regulations of sports federations at various levels: global, continental, national or club. ${ }^{17}$

The research conducted by the author shows that only $43.1 \%$ of athletes earn a full living with their sports work. ${ }^{18}$ Therefore, athletes have a real need to develop and pursue a dual career. Some universities in Poland already provide athletes with such opportunities. ${ }^{19}$ Some instruments applied in the implementation of the WLB concept can also be effectively used in reconciling performance of sports work with other gainful employment, which would provide the athlete with means necessary for everyday life and to pay for training.

Irrespective of the above conclusions, an athlete can use non-legal WLB tools including, among others: doing other physical activity, spending time with family and friends, pursuing their passions, taking a break from social media or organising trips. Traditionally understood legal instruments in the scope of the work-life balance can be used to only a small extent in the case of athletes which is strictly related to the characteristics of sports work.

\section{References}

Crompton, R. and Lyonette, C., Work-life 'balance' in Europe, "GeNet Working Paper" 2005, No. 10, https://journals.sagepub.com/doi/abs/10.1177/.

Fleetwood, S., Why work-life balance now? "Lancaster University Management School Working Paper", 2006, No. 41.

17 Kubot, Z., Statusy zatrudnienia sportowców profesjonalnych, in: Baran, K. (ed.), System prawa pracy. Tom VII. Zatrudnienie niepracownicze, Warszawa 2015, pp. 341-345.

18 Within the studies conducted in the period between December 2018 and July 2019 I prepared several dozens of surveys addressed at professional athletes, the results and analysis of which are included in my doctoral thesis 'Sports Contract'.

19 The dual career programme is carried out, among others, at the University of Physical Education and Tourism in Bialystok, where it is possible to follow the curriculum of bachelor's and master's degree studies within the dual career programme student-athlete. The programme is addressed to national team players, students with the master class or first class status and league club players (at least 2nd league). Information available on the website: http://wswfit.com.pl/s,program_kariera dwutorowa_student_sportowiec,726.html (accessed 02.12.2019). 
Guest, D., Perspectives on the study of work-life balance, "Social Science Information" 2002, Vol. 41, Issue 2.

Hildt-Ciupińska, K., Work-life balance a wiek pracowników, "Bezpieczeństwo Pracowników” 2004, No. 10.

Kodeks Dobrego Zarządzania dla Polskich Związków Sportowych, Ministry of Sport and Tourism, Warszawa 2018, https://www.msit.gov.pl/pl/aktualnosci/7622,KodeksDobrego-Zarzadzania-dla-Polskich-Zwiazkow-Sportowych.html.

Kubot, Z., Statusy zatrudnienia sportowców profesjonalnych, in: Baran, K. (ed.), System prawa pracy. Tom VII. Zatrudnienie niepracownicze, Warszawa 2015.

Pietras, A., O zakresie podmiotowym prawa pracy z perspektywy koncepcji work-life balance, "Acta Universitatis Lodziensis. Folia Iuridica” 2019, No. 88.

Raport z pogłębionej analizy danych zastanych: rozwiązania na rzecz godzenia życia zawodowego i rodzinnego $w$ Polsce, October 2016, No. 10, www.kapitalludzki.gov.pl.

Riordan, C., Work-life balance - tu nie chodzi o równowage, https://www.hbrp.pl/b/work-life-balance---tu-nie-chodzi-o-rownowage/DQ725mbo?NO_COOKIES=1.

Robak, E. and Słocińska, A., Równoważenie pracy z życiem osobistym pracowników jako istotny czynnik warunkujący gospodarowanie współczesnymi zasobami pracy, "Studia Ekonomiczne. Zeszyty Naukowe Uniwersytetu Ekonomicznego w Katowicach" 2016, No. 257.

Tausig, M. and Fenwick, R., Unbinding time: alternate work schedules and work-life balance, "Journal of Family and Economic Issues" 2001, No. 22.

White, M. et al., High-performance' management practices, working hours and work-life balance, "British Journal of Industrial Relations" 2003, Vol. 41, Issue 2. 